\title{
1. Harmony, policy and power
}

\section{A. THE TANGLED ENTICEMENT OF "HARMONISATION"}

\section{The Reality of a Transnational Copyright World}

"Harmonisation" is such a lovely word. It conjures images of sweetness and light, of goodwill and fellowship. Turn the word into the phrase "global harmonisation" and we encounter a sense of peace and tranquillity. It is easy to see harmonisation in the abstract as a good thing; to be contrasted with dissonance, a condition to be avoided.

Thus, we reflexively think of harmonisation of laws across national borders as necessarily desirable. In so doing, we may often avoid the troublesome question of the consequences of cross-border uniformity, eliding consideration of the nature and quality of the end product. In short, it is easy to see transnational harmonisation as a desirable end in itself irrespective of the substance of the "harmonised" law. That world vision has provided a significant impetus to the search for ways to create global intellectual property laws, to provide greater uniformity, harmonisation, as it were, across national borders in the field of copyright law, in particular. The impetus for a transnational copyright law, a law concerned with the intangible interest encompassed by the word "copyright", seems to be a natural extension of the inherently transnational world contemplated by borderless commerce conducted via an intangible internet. Thus a traditionally territorial, nation-based body of law, such as copyright law, seems, with its strong internet presence, and the opportunity for large scale cross-border dissemination and, concomitantly, infringement, to have become essentially and irrevocably transnational.

The resultant need for varying degrees of uniformity has serious practical ramifications, well beyond the sense of well-being associated

1 We indeed must begin with our orthographic disharmony; the US and the UK cannot agree on the preferred spelling for the subject word: is it "harmonization" or "harmonisation"? For a kind of consistency, we will use the UK spelling. 
with the abstract idea of "harmonisation". The realities of communications immediacy, the borderless world of the internet, the nature and scope of trafficking in and infringement of intellectual property rights, all make clear that harmonisation serves an important purpose, irrespective of the warmth of feeling good. Of course, there is a price attached to movement toward uniformity: both an immediate price and a structural, long-term price.

The "territoriality" principle has been a foundation of national copyright law, having become virtually axiomatic. The idea that jurisdiction over a claim for infringement of copyright requires that the acts giving rise to the claim occur essentially within the nation whose copyright law is invoked is so ingrained as to be simply a matter of doctrine, a bright-line rule, rather than a rule of analysis. ${ }^{2}$ The principle has generally worked well. Indeed, one may consider the Berne Convention ${ }^{3}$ focus on national treatment for a national of a contracting state suing for copyright infringement in another contracting state ${ }^{4}$ as embodying the territoriality principle. For the most part, national law has been sufficient to deal with acts of infringement occurring within a national border. The courts have been creative in evolving doctrine to deal with the idiosyncratic situation. Thus, it has been held that the law of the place where alleged acts of infringement occur will determine the issue of liability, ${ }^{5}$

2 See, e.g., Tire Engineering $v$ Shandong Linglong Rubber Co, 682 F.3d 292, 306 (4th Cir. 2012), cert. denied, 133 S.Ct. 846 (2013) ("As a general matter, the Copyright Act is considered to have no extra-territorial reach"). This does not necessarily mean that a court will not have jurisdiction over a foreign copyright claim (in the UK see Lucasfilm v Ainsworth [2011] UKSC 39, [2012] 1 AC 208).

3 The Berne Convention for the Protection of Literary and Artistic Works, 1161 UNTS 18338.

4 "Members of the Berne Union agree to treat authors from other member countries as well as they treat their own": Golan v Holder, 132 S.Ct. 873, 878 (2012).

5 In the United States, see Itar-Tass Russian News Agency v Russian Kurier Inc, 153 F.3d 82, 91 (2d Cir. 1998); in the European Union see Rome II Regulation (EC) No. 864/2007, art 8. There are two schools of thought over whether this rule comes from Berne Convention, art 5(2). On one side see Jane Ginsburg and Sam Ricketson, International Copyright and Neighbouring Rights, The Berne Convention and Beyond (2nd edn., Oxford University Press, Oxford 2005), [20.36] and Eugene Ulmer, Intellectual Property Rights and the Conflict of Laws (Kluwer, Alphen aan den Rijn 1978), 10-11; on the other see Richard Fentiman, "Choice of Law and Intellectual Property" (2005) 24 IIC (International Review of Industrial Property and Copyright) Studies 129, 135 and Mireille Van Eechoud, Choice of Law in Copyright and Related Rights: Alternatives to the Lex 
while in some jurisdictions the country of the origin of the work will determine the claimant's ownership of copyright. ${ }^{6}$

"Territoriality" has worked however, in a linear world, a world in which discrete acts of infringement generally occurred in discrete geographical locations, with multiple acts taking place over extended times in different places. As the world has become both non-linear and, in Thomas Friedman's words, "flat", 7 the discrete event tends to disappear and the copying and dissemination of copyrighted material exist in an instantaneous and borderless cyberspace. In this "hyperworld" borders are arbitrary and "territory" has no real meaning for something that has no "place" as such. In short, at least arguably, to some extent there is a need for a transnational law to deal with the transnational realities of the present copyright world.

\section{A Toolbox and Vocabulary for the New World}

Words are elusive; they can mean different things to different people. The freighted word "harmonisation" has protean characteristics. ${ }^{8}$ The word often evokes its musical origins, the creation of a musical "harmony." 9

Protectionis (Kluwer, Alphen aan den Rijn 2003), 107. The French Cour de Cassation recently held that Berne art 5(2) is a choice of law provision: $M$. Fabrice $X \vee L a$ société ABC News Intercontinental Inc, Cour de Cassation (Première chambre civile, 10 April 2013) No 11-12.508; but the Court of Justice appears to suggest that it is not: C-28/04 Tod's and Tod's France [2005] ECR I-5781, [32].

6 This rule applies in the United States. See Itar-Tass Russian News Agency $v$ Russian Kurier, Inc, 153 F.3d 82 (2d Cir. 1998); but not in Australia Re Enzed Holdings [1984] FCA 373 or France M. Fabrice X v La société ABC News Intercontinental Inc, Cour de Cassation (Première chambre civile, 10 April 2013) No 11-12.508. It is argued that it does not apply in the U.K. either; Phillip Johnson "Which Law Applies? A reply to Professor Torremans" (2005) 1 Journal of Intellectual Property Law and Practice 71 (which has a similar provision to Australia), but others disagree, Paul Torremans "Which law applies? A reply from Professor Torremans to Phillip Johnson's reply to his earlier work" (2005) 1 Journal of Intellectual Property Law and Practice 76.

7 Thomas L. Friedman, The World is Flat (Farrar, Straus \& Giroux, New York 2005).

8 Mads Andenas et al, "Towards a Theory of Harmonisation" in Mads Andenas and Camilla Baasch Andersen (eds), Theory and Practice of Harmonisation (Edward Elgar Publishing, Cheltenham, UK and Northampton, MA, USA 2012), 572 at 576.

9 Martin Boodman, "The Myth of Harmonisation of Laws" (1991) American Journal of Comparative Law 699, 700-1; also see Stelios Andereadakis, 
Yet this comparison is totally misplaced. Musical harmony arises where sounds fit together so as to produce something better than its parts. ${ }^{10}$ Legal harmony is completely different, as it seeks something akin to one new long single note. Certainly, a plethora of words could be used to suggest laws being brought together, including "integration", 11 "homogenization"12 or "convergence". ${ }^{13}$ Indeed, "harmonisation" is sometimes contrasted with "uniformity", the former suggesting having laws come closer together whereas the latter involves making the laws the same. ${ }^{14}$ The sameness, even with uniform rules, as will be explained in Chapter 2 , may not actually be the same, as the legal environment will differ and different interpretations might arise from use of the same or similar words. ${ }^{15}$

The advantage of using the word "harmonisation", rather than "uniformity", is that the former suggests the bringing together of differing

"Regulatory Competition or Harmonisation: The dilemma, the alternatives and the prospects of Reflexive Harmonisation" in Mads Andenas and Camilla Baasch Andersen (eds), Theory and Practice of Harmonisation (Edward Elgar Publishing, Cheltenham, UK and Northampton, MA, USA 2012), 52 at 57.

10 A point made, slightly differently, in David Leebron, "Claims for Harmonisation: A Theoretical Framework" (1996) 27 Canadian Business Law Journal 63, 67.

11 See Anne Kjaer, "A Common Legal Language in Europe" in Mark van Hoecke (ed.), Epistemology and Methodology of Comparative Law (Hart Publishing, Oxford 2004), 377 at 378.

12 Gerrit Betlem, "Beyond Francovich: Completing the Unified Member State and EU Liability Regime: A Comment on the Jan Jans Contribution" in D. Obradovic and N. Lavranos (eds), Interface between EU Law and National Law (Europa Publishing, Groningen 2007), 297 at 305-6 (uses the word "homogeneity").

13 Stelios Andereadakis, "Regulatory Competition or Harmonisation: The dilemma, the alternatives and the prospects of Reflexive Harmonisation" in Mads Andenas and Camilla Baasch Andersen (eds), Theory and Practice of Harmonisation (Edward Elgar Publishing, Cheltenham, UK and Northampton, MA, USA 2012), 52 at $60-1$.

14 Francesco Berlingieri, "Unification and Harmonisation of Maritime Law Revisited" (2006) 59 Revue Hellénique de Droit International 603, 603; also see Stelios Andereadakis, "Regulatory Competition or Harmonisation: The dilemma, the alternatives and the prospects of Reflexive Harmonisation" in Mads Andenas and Camilla Baasch Andersen (eds), Theory and Practice of Harmonisation (Edward Elgar Publishing, Cheltenham, UK and Northampton, MA, USA 2012), 52 at $57-8$.

15 On the need for real uniformity see Francesco Berlingieri, "Unification and Harmonisation of Maritime Law Revisited" (2006) 59 Revue Hellénique de Droit International 603, 604 and 613. 
concepts from various sources, essentially involving an active process of accommodation, rather than the external imposition implied by "uniformity". Thus, we prefer, and will use, the term "harmonisation" throughout to reflect the ultimate engagement of those players who will be bound as the process develops.

Agreement on a word does not itself eliminate uncertainties and ambiguities. For example, there may be different degrees of harmonisation: from "minimum" harmonisation, in the form of the imposition of a set of minimum standards, to a maximum or full harmonisation, whereby there is no room for divergence between the various legal systems. ${ }^{16}$ Indeed the differences are more subtle and nuanced than even these words convey. Minimum standards can be set for a "bottom" level or a "top" level of regulation (bottom level: you must have copyright protection for at least the life of the author plus 50 years; top level: copyright exceptions must not go further than that permitted by the three-step test). A "full" harmonisation can be complete harmonisation of the substantive rules (the meaning of "substantial part" for instance ${ }^{17}$ ), the rules and remedies (an injunction must be available ${ }^{18}$ ) or the rules, remedies, and legal procedures (there must be discovery and it includes $\left.\mathrm{X}^{19}\right)$.

The outcome of legal disputes most often turns on procedure, rather than substantive law. ${ }^{20}$ Accordingly, if the aim of harmonisation is to have the same outcome arising in two different countries based on identical facts then full harmonisation of substantive law will not be enough. Yet reality must intrude. Assuming that "full" harmonisation of the substance of copyright law is achievable, "fullness" is a more elusive matter and thus we prefer to think in terms of "effective" or workable harmonisation. That is, our focus is on the possibility of a copyright regime that, without quibbling as to its lacunae, effectively affords a

16 See Ruth Sefton-Green, "Multi-culturalism, Europhilia and Harmonization: Harmony or Disharmony" (2010) 6 Utrecht Law Review 50, 50-1 (she also uses the word "complete" harmonisation, at 66).

17 E.g. Directive 2001/29/EC, art 3 and C-5/08 Infopaq [2009] ECR I-6569.

18 E.g. Directive 2004/48/EC, art 9 and 11.

19 E.g. the Proposal for the Recast Trade Marks Directive (COM (2013) 162 final) (albeit these are procedures for the grant of a trade mark, not infringement) and the more recent drafts of the proposal have moved away from complete procedural harmony).

20 An obvious point, but one rarely made; for a notable exception see, Sir Robin Jacob, "International Intellectual Property Litigation in the Next Millennium" (2000) 32 Case Western Reserve Journal of International Law 507, 507. 
workable kind of transnational uniformity. ${ }^{21}$ The creation of a new court applying new rules to copyright disputes is much further away and probably still out of reach.22

In the United States, the dual federal-state system has long accommodated an array of separate, independent federal and state laws, with parallel federal and state court systems and related governmental bodies (although in certain defined areas the system acknowledges the primacy of federal substantive law). More significantly, at the state law (or common law ${ }^{23}$ level), there is an array of "uniform" laws, sets of statutes more or less adopted uniformly by the several states, ${ }^{24}$ superseding to one extent or another the 50 sets of state laws. Periodically, the National Conference of Commissioners on Uniform State Laws ${ }^{25}$ will determine that the benefits of uniformity in certain areas of the law will outweigh the benefits of separate state experimentation and variation and propose a "uniform" statutory codification of the body of law for action by the several state legislatures. Sometimes, as with the Uniform Commercial

21 A similar definition of uniformity is used by Camilla Baasch Andersen, "Applied Uniformity of a Uniform Commercial Law: Ensuring Functional Harmonisation of Uniform Texts through a Global Jurisconsultorium of the CISG" in Mads Andenas and Camilla Baasch Andersen (eds), Theory and Practice of Harmonisation (Edward Elgar Publishing, Cheltenham, UK and Northampton, MA, USA 2012), 30 at 32 ("we can define 'uniformity' as the varying degree of similar effects on a phenomenon across boundaries of different jurisdictions resulting from the application of deliberate efforts to create specific shared rules in some form").

22 For example, the attempts to create a Community Patent Court (now Unified Patent Court) appear to be approaching the final hurdle, but this is after two previous failed attempts and more than 40 years since it started. Even then it is purely an intra-EU project and two countries (Poland and Spain and to a lesser extent Italy) are not part of the agreement.

23 There is no federal "common law"; see, e.g., Liddy $v$ Wells, 186 F.3d 505 (4th Cir. 1999), cert. denied 120 S. Ct. 939 (2000), a defamation action involving multiple acts of slander and libel occurring both in different states and on the high seas. The court laboriously determined which state laws of defamation were applicable to which of the state-based claims, but found itself in an anomalous position with respect to an applicable common law to apply to a slander on the high seas, ultimately retreating to an open-ended law of admiralty.

24 The most prominent, and most "uniform", being the Uniform Commercial Code. Of course where there is widespread adoption the "uniformity" comes from individual states enacting similar legislation, so that with respect to any one state, the focus remains the state's law, even if it happens to be the same as that of most other states following adoption of that "uniform" law.

25 Sometimes in conjunction with the American Law Institute, another non-governmental organisation. 
Code, over a period of years all, or virtually all, of the respective legislatures will adopt the proposed law, or a close variant of it, producing the desired "uniformity", and at other, more frequent times, the legislation will be adopted by few, if any, state legislatures. ${ }^{26}$

Concurrently, where there may be overlap between federal and state power, statutory or constitutional doctrines of federal pre-emption may operate to create in effect a superseding federal law, ${ }^{27}$ providing national uniformity. ${ }^{28}$ Thus, for example, when the US Copyright Act of 1976 was enacted, ${ }^{29}$ one of its most significant changes was to replace the then existing dual system - in which prior to publication a work was protected by state law (the so-called "common law copyright") and, upon publication, the work lost its state protection and either fell into the public domain or, if published with appropriate notice, became subject to the federal copyright law - with a single, unitary system, governed solely by federal law, state law being explicitly pre-empted..$^{30}$

Uniformity as among the states of one nation or the member states of a union of nations, while promoting efficiency comes with a cost. This consideration, a cost/benefit efficiency analysis, of course, permeates issues of "uniformity" as among the Member States of the European Union. ${ }^{31}$ Although sharing a significant common core, the various Member States exhibit a degree of diversity in the details of their respective national laws that is often overlooked by the non-European observer. Just as there is no "American" criminal law applicable as a code to all the states, ${ }^{32}$ so there is no "European" all-embracing criminal code (although there is work towards a civil code). Not surprisingly, the European nation-state remains in relatively full flower; the emergence of

26 Such was the fate of the languishing Uniform Computer Information Transactions Act (adopted only in Maryland and Virginia) and only one state, Pennsylvania, ever adopted the Uniform Written Obligations Act.

27 See, e.g., Sears, Roebuck \& Co v Stiffel Co., 376 U.S. 225 (1964); see Jeanne C. Fromer, "The Intellectual Property Clause's Preemptive Effect" (2012) 61 Duke Law Journal 1329.

28 Similarly, this is meant to occur under EU law, particularly where something falls under the European Union's exclusive competence as some aspects of copyright appear to do (see Chapter 4, Part C.3).

2917 U.S.C. $\$ 101$ et. seq.

3017 U.S.C. $\$ 301$.

31 See, e.g., Mireille van Eechoud et al, Harmonizing European Copyright Law: The Challenges of Better Lawmaking (Kluwer, Alphen aan den Rijn 2009).

32 As opposed to those specific areas of law reserved to the federal government. 
a "euro zone" may indeed have been even more surprising to "Europeans" than it was to the rest of the world! In short, harmonisation even within the relatively homogenous US state system, just as in the comparatively cognate civil law systems of the Member States of the European Union, can be a mixed blessing.

It is overly simplistic to pin absolute values on the construct of harmonisation of laws. A code, an all-embracing uniformity across national borders with respect to some area of law is not per se good or bad; it serves a variety of purposes, from administrative efficiency to the promotion of a degree of cultural homogeneity, but often at the price of obscuring significant cultural or societal differences and precluding useful experimentation and variation. That is, in any given instance, the decision to adopt one or another form of legislation that results in transnational uniformity of law requires balancing a variety of considerations and the choice is ultimately a policy determination. As we elaborate below, one of our principal concerns, in considering the nature and scope of possible harmonisation of copyright law, is to distinguish issues of policy from those of power; examining where the differing competencies as between the United States and the European Union may converge so that the implementing policy issues may be realistically understood and resolved.

Although we discuss at length the nature and possible scope of harmonisation of copyright law as between the United States and the European Union it is still too early to suggest that there exists today a harmonised EU law of copyright fully pre-empting the laws of the Union's Member States. ${ }^{33}$ Nevertheless it is necessary to begin somewhere. With respect to copyright law, exogenous factors, an interconnected supra- or trans-national universe in which copyrighted matter is created, distributed and used, roughly analogous to those exogenous factors that impel particular moves to uniformity of state laws in the United States and the array of existing European Union Directives, along with an existing body of treaties and international agencies, create a degree of urgency in approaching those matters of power and policy. These are matters that cabin the construct of global (or, at least, transatlantic) uniformity of law. We recognise that, at this time, to speak in terms of "globalisation" is redolent of grandiosity and thus our concerns here begin with the somewhat more practicable prospect of transatlantic harmonisation, limiting our present scope to the nonuniversal universe encompassed by the United States and the European

33 But as we will see in Chapter 4, this appears to be incredibly close. 
Union. In this context, it is then necessary to examine more closely what in fact real harmonisation entails. It is not simply ${ }^{34}$ a matter of arriving at a multilateral policy consensus that produces a uniformly applied transnational code.

Rather, sophisticated analysis necessarily implicates structural and cultural issues, and questions of both power and policy, that, unless addressed and reframed, create enormous hurdles to meaningful harmonisation: (i) the United States is and will remain for the foreseeable future, a major player in the intellectual property world and while there may certainly be intra-European benefits to a "European" copyright law, there cannot be anything approaching serious international harmonisation of copyright law without the active involvement of the United States; (ii) such moves toward harmonisation as have been adopted in the past, have, almost without exception, taken the form of treaties increasing the rights and protections of copyright owners, ${ }^{35}$ with limited ${ }^{36}$ parallel movement in the direction of uniform exceptions and limitations on those rights; ${ }^{37}$ (iii) unlike the states of the European Union, in which the impetus for assuming treaty obligations is to be found in policy determinations, and the array of EU competencies, ${ }^{38}$ for the United States, alongside considerations of policy are (usually tacit) serious considerations of constitutional power, questions of the scope of and limitations on congressional power to enact copyright legislation; (iv) consequently, the present harmonisation regime, an accretion from "national treatment" treaties to minimal standards agreements based on expansion of rights, with ever-broadening power without concomitant limiting exceptions, creates serious constitutional implications for the US system, going to the power of the US Congress to act. These implications of power and competency must be examined and accommodated by policy determinations resulting in any meaningful uniform copyright regime. ${ }^{39}$

34 And of course that would not be at all simple.

35 See Chapter 2, Part C.

36 A recent exception to this is the Marrakesh Treaty to Facilitate Access to Published Works for Persons who are Print Disabled (agreed 28 June 2013) (not yet in force).

37 See, e.g., P. Bernt Hugenholtz and Ruth L. Okediji, Conceiving an International Instrument on Limitations and Exceptions to Copyright (Amsterdam Law School Legal Studies Research Paper No. 2012-43, Institute for Information Law Research Paper No. 2012-37 (2008)) (despite over a century of international norm setting in the field of copyright, limitations and exceptions have largely remained unregulated space).

38 See Chapter 4, Part C.

39 See Chapter 3. 
Technological change, rather than considered power/policy analysis, has been the driving force in recent moves toward a degree of uniformity in intellectual property law. Technological urgency, as well as the technological "lag" in most legislation, has been the impetus for past efforts to accommodate copyright law to the exigencies of a digital, internet-based, constantly available, borderless world. ${ }^{40}$ The emergence of the internet produced an urgency to meet this unanticipated phenomenon, best exemplified by the explosion of the alphabet soup of treaties, protocols, agreements and enforcing agencies that have emerged over the past several decades. From Berne and GATT, ${ }^{41}$ we have moved to TRIPS, ${ }^{42} \mathrm{WTO}^{43}$ and WIPO. ${ }^{44}$

This aggregation of acronyms has been the launching point and rationale for a plethora of legislation, all designed to conform US law to that of the European Union and both more generally to the world at large. That is, as a matter of policy their governments have found it to be in the national (regional) interest to accede to an array of treaties and protocols, an accession process that, for example, in the United States required not only Congressional ratification, but the enactment by Congress of implementing legislation. Although there is certainly nothing unusual in this mode of international relations, as discussed below, much of the past and projected implementing legislation, enhancing, as it does, the scope or nature of copyright protection, gives rise to serious constitutional questions relating to the exercise of congressional power.

Consistent with the European Union's ${ }^{45}$ Rental Rights Directive, ${ }^{46}$ Term Directive ${ }^{47}$ and Information Society Directive, ${ }^{48}$ the US Congress

40 The tensions between technology and copyright are as old as copyright itself: see Brad Sherman and Leanne Wiseman (eds), Copyright and the Challenge of the New (Kluwer, Alphen aan den Rijn 2012), passim.

41 General Agreement on Tariffs and Trade, 55 UNTS 187 (this is the original version of the GATT).

42 Agreement on Trade-Related Aspects of Intellectual Property Rights (TRIPS), Marrakesh Agreement Establishing the World Trade Organization, 1867 UNTS 31874, Annex 1C.

43 Marrakesh Agreement Establishing the World Trade Organization, 1867 UNTS 31874.

44 World Intellectual Property Organization: Convention Establishing the World Intellectual Property Organization, 828 UNTS 11846.

45 At the time the European Economic Community (and then the Economic Community).

46 Directive 92/100/EEC (now codified as Directive 2006/115/EC).

47 Directive 93/98/EEC (now codified as Directive 2006/116/EC).

48 Directive 2001/29/EC. 
enacted in 1998, the Uruguay Round Implementation Act, the Sonny Bono Copyright Term Extension Act and the Digital Millennium Copyright Act (the first implemented TRIPS, so as to create an antibootlegging right, the second directly increased the term of copyright in the United States to conform to that of the European Union, ${ }^{49}$ and the third enacted an array of provisions including, among other things, the imposition of liability for circumvention of technological measures limiting access to copyrighted material and the imposition of "copyright management" obligations expressly to implement the 1996 WIPO Copyright Treaty and the WIPO Performances and Phonograms Treaty). What is of particular importance to any discussion of harmonisation, and makes such harmonisation uniquely difficult, is that these legislative enactments were met immediately with challenge in the courts. The legal bases for the challenges could not relate directly to the wisdom (or lack thereof) of the policies involved; rather, it was argued that the legislation could not withstand US constitutional scrutiny as an exercise of the constitutional grant of power to Congress to legislate with respect to copyright. The fact that the legislation was ultimately upheld against constitutional challenge (by the Supreme Court in the case of the copyright term extension ${ }^{50}$ and by US courts of appeals in the case of the anti-circumvention provisions $^{51}$ and bootleg recordings ${ }^{52}$ ) does not mitigate the fact that such significant legislative changes to US law necessarily implicate serious issues of constitutional power.

49 Essentially, by adding 20 years to the copyright term; the European Union has also exported its standards more generally by way of free trade and bi-lateral agreements: see Bernt Hugenholtz, "Is Harmonization a Good Thing? The Case of the Copyright Acquis" in Ansgar Ohly and Justine Pila (eds), The Europeanization of Intellectual Property Law: Towards a European Legal Methodology (Oxford University Press, Oxford 2013), 57 at 65.

50 Eldred v Ashcroft, 537 U.S. 186 (2003), in which, among other matters, the Court rejected the argument that periodic congressional increase in the term of copyright had the effect of violating the constitutional requirement that copyright endure only for "limited times".

51 Universal City Studios Inc. v Corley, 273 F.3d 429 (2d Cir. 2001) (upholding the anti-circumvention provisions against the argument that they violated the First Amendment guarantee of freedom of speech).

52 United States v Moghadam, 175 F.3d 1269, 1280 (11th Cir. 1999); United States $v$ Martignon, 492 F. 3d 140, 151 (2d Cir. 2007) (upholding the antibootlegging statute as a valid exercise of Congressional Commerce Clause power); United States v Moghadam, 175 F.3d 1269, 1280 (11th Cir. 1999) was applied to anti-circumvention devices in United States v Elcom, 203 F Supp 2d 1111, 1138-42 (ND Cal 2002). 
In short, significant moves toward harmonisation that involve expansion of rights of authors or copyright owners must necessarily require a constitutional power analysis. Concomitantly, if we are to consider movement toward harmonisation, rather than continuation of a regime of minimum standards, we need a greater understanding of the scope of EU competencies; that is, the policy/power construct surrounds the proposition of a "harmonised" EU copyright law alongside the similar concerns about a uniform law that embraces both the European Union and the United States. That analysis follows. The analysis, as is also discussed below, must implicate similar constitutional constraints and imperatives, so that a truly harmonised regime must include, (i) for the European Union, an accommodation to the US broader concerns with limitations on and exceptions to the rights of copyright authors and owners and (ii) for the United States a fuller and more detailed regime for related rights. It is becoming increasingly clear that the same centripetal technological forces leading toward some form of transnational uniformity also, and necessarily, lead toward copyright regimes that more openly accommodate the interests of users and the public alongside those of authors and rights holders.

\section{B. A CLOSER LOOK AT HARMONISATION AND CULTURE}

\section{Why?}

The harmonisation of law has been an aspiration of the international legal scholar since the fall of the Roman Empire (and with it the end of a uniform Roman law). ${ }^{53}$ The real question is not whether harmonisation as a concept is good or bad, but whether the particular harmonisation contemplated is, on balance, good or bad. We suggest that a form of harmonisation of copyright law is both necessary and desirable. As a predicate, some observations need to be made about the general issues raised by any form of "harmonisation". The classic reason for harmonisation is economic: local legal differences make legal compliance more expensive and so make international trade more difficult. ${ }^{54}$ Put in

53 Hessel E. Yntema, "Comparative Research and Unification of Law" (1942) 41 Michigan Law Review 261, 265.

54 See for example, Jurgita Malinauskaite, "International Competition Law Harmonisation and the WTO, Past Present and Future" in Mads Andenas and 
economic terms, harmonisation reduces transaction costs. ${ }^{55}$ Businesses frequently have to ensure compliance with two or three or more sets of laws (which may in turn lead them to applying the most restrictive law). Such over-compliance adds costs and reduces efficiency.

Further, harmonisation of law eventually leads to increased foreseeability and predictability of legal results. ${ }^{56}$ However, a new harmonised law requires adaptation and can lead to confusion and, at least initially, a multiplicity of result. This is clearly what happens currently in the European Union, where national courts apply the EU law through national lenses: but over time interpretative differences are slowly ground into a more uniform shape as the Court of Justice decides the issues. ${ }^{57} \mathrm{~A}$ similar process, albeit less pronounced, happens in the United States when two Circuit Courts of Appeal adopt different approaches to the same federal law which are brought together only by a decision of the US Supreme Court.

In short, the rationale for harmonisation is largely going to be based on economic and not legal grounds. ${ }^{58}$ As the US government put it in relation to patents:

Camilla Baasch Andersen (eds), Theory and Practice of Harmonisation (Edward Elgar Publishing, Cheltenham, UK and Northampton, MA, USA 2012), 323 at 328-9.

55 Saul Levmore, "Harmonisation, Preferences, and the Calculus of Consent in Commercial and Other Law" (2013) 50 Common Market Law Review 243, 243.

56 Mads Andenas et al, "Towards a Theory of Harmonisation" in Mads Andenas and Camilla Baasch Andersen (eds), Theory and Practice of Harmonisation (Edward Elgar Publishing, Cheltenham, UK and Northampton, MA, USA 2012), 572 at 588.

57 A similar point is made by Bernt Hugenholtz, "Is Harmonization a Good Thing? The Case of the Copyright Acquis" in Ansgar Ohly and Justine Pila (eds), The Europeanization of Intellectual Property Law: Towards a European Legal Methodology (Oxford University Press, Oxford 2013), 57 at 67.

58 A similar point is made by Christopher Heath, "Methods of Industrial Property Harmonisation - The Example of Europe" in Christoph Antons, Michael Blakeney and Christopher Heath (eds), Intellectual Property Harmonisation within ASEAN and APEC (Aspen Publishers, New York 2004), 39. Indeed, it has been pointed out that economic or free market arguments are going to be more important in relation to intellectual property than in other areas of law: Jan Smits and William Bill, "The Europeanization of Patent Law: Towards a Competitive Model" in Ansgar Ohly and Justine Pila (eds), The Europeanization of Intellectual Property Law: Towards a European Legal Methodology (Oxford University Press, Oxford 2013), 39 at 42. 
A harmonised world patent system is essential because companies around the world are increasingly reliant on global markets; thus, the differences that exist today among national or regional patent offices may act as an impediment to inventors and hinder opportunities for greater trade among nations. ${ }^{59}$

Harmonisation is not purely about transaction costs: a plurality of different legal regimes creates different market conditions and presents greater business opportunities ${ }^{60}$ or a greater chance of finding optimal business outcomes (put another way, there is regulatory competition between jurisdictions to attract actors to that jurisdiction ${ }^{61}$ ). Thus, in economic terms some firms will prefer to remove the cost of switching between legal systems while others might benefit from this divergence. ${ }^{62}$ The costs/benefit analysis will also depend on the nature of the harmonisation. Where there is a minimum harmonisation, rather than full harmonisation, there is still divergence as a floor (or ceiling) exists but otherwise the standards vary between legal systems. The costs associated with harmonisation must also include the costs of "implementation" including the mechanical changes to the law, the costs associated with new advice be it official or privately provided and the costs with the change of contracts, both past and future, among other matters. Thus, the question of whether harmonisation is a good thing depends on whether or not these transition costs are greater, or less than, the transaction costs caused by the present divergence.

\section{Why Not?}

Of course, harmonisation is not always good. To suggest otherwise is naïve in the extreme. A diversity of laws may be necessary and

59 US General Accounting Office, Intellectual Property Rights - U.S. Companies Views on Patent Law Harmonisation (1993) (GAO/T-GGD-94-11) (Allan Mendelowitz), 1.

60 Saul Levmore, "Harmonisation, Preferences, and the Calculus of Consent in Commercial and Other Law" (2013) 50 Common Market Law Review 243, 248-9.

61 Stelios Andereadakis, "Regulatory Competition or Harmonisation: The dilemma, the alternatives and the prospects of Reflexive Harmonisation" in Mads Andenas and Camilla Baasch Andersen (eds), Theory and Practice of Harmonisation (Edward Elgar Publishing, Cheltenham, UK and Northampton, MA, USA 2012), 52 at 54.

62 Saul Levmore, "Harmonisation, Preferences, and the Calculus of Consent in Commercial and Other Law" (2013) 50 Common Market Law Review 243, 248. 
particularly appropriate to respond to special or local situations. ${ }^{63}$ Indeed, the transplant of a new legal rule from elsewhere can be dangerous. Each legal rule has a context and it is important that the rule and its context are taken into account before any new rule is adopted. ${ }^{64}$ To give a simple example in the copyright context, the US doctrine of fair use is built upon more than a century of case law and elucidation and a foundation of legal flexibility only hinted at by the statutory language. ${ }^{65}$ The simple copying of the statutory words into another law, such as occurred in Israel, ${ }^{66}$ leads to difficult questions. Does the US jurisprudence come along with the words? Or does Israel start from scratch, interpreting and applying these words without their generative cultural context but within their new context? If the latter, then it is quite likely that "fair use" would mean very different things in the two different countries. ${ }^{67}$

Further, harmonisation, and in particular full harmonisation, can be a straitjacket stifling legal reform and the improvement of the substantive law. ${ }^{68}$ For example, as interest in an American version of droit moral grew in the United States, several states adopted their own "moral right" statutes; 69 when Congress, largely under pressure to have greater facial compliance with the Berne Convention, ${ }^{70}$ ultimately enacted the Visual Artists Rights Act of $1989,{ }^{71}$ adding to the Copyright Act a limited moral right, it expressly pre-empted state law. ${ }^{72}$ This in turn prompted serious scholarly concern that the newly emerging doctrine in the United States

63 See, for instance, R. Graveson, "The International Unification of Law" (1968) 16 American Journal of Comparative Law 4, 5-6.

64 Otto Kahn-Freund, "On the Uses and Missues of Comparative Law" (1974) Modern Law Review 1.

65 See Chapter 3, Part A.5 and Chapter 5, Part A.2.

66 Copyright Act 2007, s 19 (the four-stage test was included with only minor changes of terminology).

67 See Chapter 5, Part A.3.

68 A point also made by Arthur Rosett, "Unification, Harmonisation, Restatement, Codification, and Reform in International Commercial Law" (1992) 40 American Journal of Comparative Law 683, 683 and 688.

69 See, e.g., California Civil Code $\$ 987$ et. seq., Preservation of Works of Art; New York Arts and Cultural Affairs Law §14.03. See generally, Sheldon W. Halpern, The Law of Defamation, Privacy, Publicity, and Moral Right (4th edn., JPm Books, Columbus, OH 2000).

70 Berne Convention, art 6bis.

71 17 U.S.C. $\$ 106 \mathrm{~A}$.

7217 U.S.C. $\$ 106 A$. 
would now be cramped and its growth inhibited by this preclusion of state experimentation. ${ }^{73}$

It is not these practical problems which cause the greatest concern to most people, but the political and ideological issues which harmonisation faces. A full harmonisation can precipitate problems of nationalism (or in Europe, Euroscepticism) and a push to promote nation identity and cultural values over the multination (or European) value or standard. ${ }^{74}$ When these clashes arise it might mean that the two (or more) legal systems are not yet ready for the harmonisation politically, socially or economically or simply that the system adopted is wrong. ${ }^{75}$ Once more, a perception from each legal system involved that its constituents are getting a good deal is what is important. ${ }^{76}$

\section{Nationalism and Culture}

As William Twinning put it, "the processes of globalisation stir up old nationalisms, exacerbate cultural conflict, and encourage post-modern scepticism about the universality of values and ideas". ${ }^{77}$ Harmonisation projects, as part of that globalisation, can create strong nationalist feeling. This can lead to some extreme suggestions. For example, when discussing a different harmonisation project, that of unifying European private law, a French scholar compared it to the identity politics of Nazi Germany, the Soviet Union and Cambodia under the Khmer Rouge, ${ }^{78}$

73 See, e.g., Roberta Rosenthal Kwall, "How Fine Art Fares Post VARA" (1997) 1 Marquette Intellectual Property Law Review 1, 3-4; Edward J. Damich, "The Visual Artists Rights Act of 1990: Toward a Federal System of Moral Rights Protection for Visual Art" (1990) 39 Catholic University Law Review 945.

74 Ruth Sefton-Green, "Multi-culturalism, Europhilia and Harmonization: Harmony or Disharmony" (2010) 6 Utrecht Law Review 50, 65.

75 Ruth Sefton-Green "Multi-culturalism, Europhilia and Harmonization: Harmony or Disharmony" (2010) 6 Utrecht Law Review 50, 66.

76 In terms of UK Euro-scepticism, the UK Government has been asked to detail the situations when the UK got what it wanted in policy negotiations in Europe and when it did not (the balance of competences): see William Hague, HC Deb, Vol 548, 12 July 2012, col 468 et seq.

77 William Twinning, "Comparative Law and Legal Theory: The Country and Western Tradition" in Ian Edge (ed.), Comparative Law in Global Perspective (Transnational Publishers, Ardsley, New York 2000), 21 at 65.

78 Yves Lequette, "Quelques remarques à propos du projet de code civil européen de M. von Bar" in Bénédicte Fauvarque-Cosson and Denis Mazead (eds), Pebsée Juridique Française et Harmonisation Européenne du Droit (Vol 1) (Société de Législation Comparée, Paris 2002), 69 at 93 ([23]) ("Le mot est fort mais nullement excessif. Se reliant à la volonté de favoriser l'émergence d'un 
suggesting that such a project is some kind of cultural genocide. ${ }^{79}$ Others have been equally outraged, calling the same project "oppressive". 80 Ironically, the converse is seen to be perfectly reasonable; when a domestic standard is exported it can lead national pride to suggest that such an export might be so significant that it can avoid conflict (even military conflict). ${ }^{81}$

Nationalist legal arguments usually suggest that harmonisation undermines national culture. ${ }^{82} \mathrm{~A}$ legal system is inseparably linked to a national identity, and it both shapes that identity and is shaped by it. ${ }^{83}$ If one accepts the idea that to harmonise changes a national identity then a harmonisation project leads to competition between national identity and the new international identity ${ }^{84}$ - between being part of a sovereign state and being part of a global community. Yet national identity is not

home nouveau, en dissolvent les citoyennetés traditionnelles dans une citoyenneté européene, l'enterprise n'évoque pas pour nous les meilleurs moments de l'histoire du siècle passé. Dans l'Allemagne nazie, l'URSS, le Kampuchéa démocratique, des minorities agissantes qui se croyaient éclairées se sont également, en leur temps et avec le success que l'on sait, employees à forger, par des voies certes bien différentes, des homes nouveuax.").

79 Ralf Michaels, "Code vs Code: Nationalist and Internationalist Images of the Code Civil in the French Resistance to a European Codification" (2012) European Review of Contract Law 277, 282.

80 P. Legrand, "Antivonbar" (2005) 1 Journal of Comparative Law 13, 27.

81 Philippe Malaurie, "Le code civil européen des obligations et des contrats - Une question toujours ouverte" in Bénédicte Fauvarque-Cosson and Denis Mazead (eds), Pebsée Juridique Française et Harmonisation Européenne du Droit (Vol 1) (Société de Législation Comparée, Paris 2002), 219 at 224 ([11]) (suggesting the Franco-Prussian war of 1870/1 could have been avoided if the Prussians had adopted the French Civil Code - "En faveur de la codification européene, il y a aussi un autre argument politique, surtout franco-allemand. Une des causes des drames qu'a traversés l'Europe depuis 1870 avec les conflits franco-allemands tient peut-être au fait qu'en 1804 la Prusee n'a pas adopté le Code civil français: une Europe paisible se serait alors constituée.”)

82 Generally, rather than just in terms of cultural policy, in which respect see below.

83 Ralf Michaels, "Code vs Code: Nationalist and Internationalist Images of the Code Civil in the French Resistance to a European Codification" (2012) European Review of Contract Law 277, 291.

84 Ruth Sefton-Green, "French and English Crypto-nationalism and European Private Law: An exercise in Sentiment and Reason" (2012) European Review of Contract Law 260, 263 (referring to European and national identity). 
"written in stone". ${ }^{85}$ It changes both passively and actively through revolutions and evolutions, through foreign influence and local influence. The idea that nothing "national" may ever be changed is a "characteristic trait of nationalist discourse". ${ }^{86}$ Relying on identity as a ground to resist harmonisation is simply a method of creating a "them" and an "us"; harmonisation is about everyone involved being an "us" and there being no "them" at all.

Nationalism, in this context, is a belief that one's own national legal system is the best system in the world and that any outside influence will taint that perfection. Thus, the issue of national identity, and tradition, is interlinked as a ground to resist harmonisation. At its simplest level, national scholars have spent generations refining and reflecting upon the national jurisprudence and the idea that it will be lost by adopting a new standard. ${ }^{87} \mathrm{~A}$ harmonised standard therefore is seen to break with a national legal tradition and replaces it with a new instrument without any tradition at all. Calls to tradition at the expense of change or development brings to mind the famous quote by the author G.K. Chesterton:

Tradition means giving votes to the most obscure of all classes, our ancestors. It is the democracy of the dead. Tradition refuses to submit to the small and arrogant oligarchy of those who merely happen to be walking about ... [Yet he continued] Democracy tells us not to neglect a good man's opinion, even if he is our groom; tradition asks us not to neglect a good man's opinion even if he is our father. 88

Tradition as an independent construct cannot, and should not, be an argument against beneficial change; just as change and departures from tradition should not be undertaken solely in the interests of a search for modernity. Societies do not live in the past and neither do lawyers. Arguments based on tradition may easily turn lawyers into luddites attempting to preserve the relevance of their training and professional

85 Ruth Sefton-Green, "French and English Crypto-nationalism and European Private Law: An exercise in Sentiment and Reason" (2012) European Review of Contract Law 260, 267.

86 Ruth Sefton-Green, "French and English Crypto-nationalism and European Private Law: An exercise in Sentiment and Reason" (2012) European Review of Contract Law 260, 268.

87 Ralf Michaels, "Code vs Code: Nationalist and Internationalist Images of the Code Civil in the French Resistance to a European Codification" (2012) European Review of Contract Law 277, 286.

88 G.K. Chesterton, Orthodoxy (Barnes and Noble, New York 2007 [1908]), 39 (this was part of an argument that democracy and tradition are compatible or indeed the same). 
skills over the development of new and better ones. Law is always about evolution and change. Tradition has never dominated the law, ${ }^{89}$ but simply guided it to ensure the persistence of the good (but often holding on to the bad for too long). It is a tool like any other and as communities evolve and grow the tools they need and use have to change to fit the new climate. Harmonisation is simply a way of fashioning a new axe made of iron rather than bronze. Yet the dogma of tradition remains an important hurdle in harmonisation debates regarding copyright.

Questions of harmonisation must reach beyond the general to the particular: is the specific change better? The determination of improvement must be judged by reason ${ }^{90}$ and not by national passion. ${ }^{91}$ For the values of lawyers and jurists are probably for nought as René David put it:

Let jurists continue in their routine opposition to international unification of law; nevertheless that unification will occur without and despite them, just as the ius gentium developed in Rome without the pontiffs, and as equity developed in England without the common-law lawyers. ${ }^{92}$

89 Ralf Michaels, "Code vs Code: Nationalist and Internationalist Images of the Code Civil in the French Resistance to a European Codification" (2012) European Review of Contract Law 277, 294. The tradition of law, in terms of the French Civil Code and EU law, was expressed as follows: "The French Civil Code, like the French nation, may once have been the essence of modernity. Against the conflicting modernity of the European Union and a European Code, it is reinvented as a pre-modern artefact, worthy of protection just because it is there".

90 It has been suggested that the use of comparative law and evaluating different legal rules might be a way of enabling the courts and others to appreciate the potential disruptions and so to make harmonisation smoother: Dagmar Schiek, "Comparative law and European harmonisation - a match made in heaven or uneasy bedfellow" in Mads Andenas and Camilla Baasch Andersen (eds), Theory and Practice of Harmonisation (Edward Elgar Publishing, Cheltenham, UK and Northampton, MA, USA 2012), 425 at 443.

91 Ruth Sefton-Green, "French and English Crypto-nationalism and European Private Law: An exercise in Sentiment and Reason" (2012) European Review of Contract Law 260, 261; also see Anthony D. Smith, "National Identity and the Idea of European Unity" (1992) 44 International Affairs 55, 55.

92 René David, "The Methods of Unification" (1968) 16 American Journal of Comparative Law 13, 14. 


\section{The "Sanctity" of Copyright as Part of National Culture}

Copyright law could affect cultural policy in at least two ways. ${ }^{93}$ First, it can be seen as a way of allowing cultural goals to be set out in precise terms. A classic, now increasingly historic, example is the question of copyright protection for immoral or obscene works. ${ }^{94}$ Thus, to further the state interest in not encouraging the production of immoral works, denial of copyright protection was seen as a way to remove the incentive to produce them. ${ }^{95}$ Secondly, copyright law can provide a conceptual framework for the expression of values underlying cultural policy. The nature of copyright is that it regulates, or more precisely allows the copyright owner to regulate, the use of cultural goods (books, films, music and so forth). Accordingly, copyright remains the primary focus of groups wishing to promote their cultural interests. ${ }^{96}$

The acceptance of culture within a copyright harmonisation project has been articulated by the Court of Justice in relation to the cultural development of the European Union ${ }^{97}$ and it is referred to as such in some EU Directives. ${ }^{98}$ Can different underlying cultural policies be recognised and accommodated under the umbrella of a harmonised

93 See Mira Rajan, "The implications of international copyright law for cultural diversity policies" in Differing Diversities: Transversal Study on the Theme of Cultural Policy and Cultural Diversity (Council of Europe 2001), 135 at $135-6$.

94 In England see, Glynn v Western Cinema [1916] 1 Ch. 261; also see Jeremy Phillips, "Copyright in Obscene Works: Some British and American Problems" (1977) 6 Anglo-American Law Review 138. The position now appears to be that copyright is not a moral test in the US: Mitchell Bros $v$ Cinema Adult Theater, 604 F 2d 852 (5th Cir. 1979) (but see Opinion Attorney-General, 171 USPQ (BNA) 329 (1958)).

95 Although ironically, without copyright dissemination of such works is easier.

96 Mira Rajan, "The implications of international copyright law for cultural diversity policies" in Differing Diversities: Transversal Study on the Theme of Cultural Policy and Cultural Diversity (Council of Europe 2001), 135 at 137.

97 C-200/96 Metronome [1998] ECR I-1953, [22]. The "culture" clause in the European Union was introduced by the Maastricht Treaty in 1992 (see Chapter 4, Part C.1). Prior to this one of this arguments against the harmonisation was the lack of a cultural competence in the EEC: Margret Moller, "On the Subject of the Green Paper" (1989) 141 Revue Internationale du Droit d'Auteur 22, 52; Gerhard Schricker, "Harmonisation of Copyright in the European Economic Community" (1989) 20 International Review of Industrial Property and Copyright Law 466, 472.

98 Directive 2001/29/EC, Recital (12). 
law?99 Must copyright be sacred, or at least more sacred than other laws, to be treated differently and to avoid the apparently homogenising net of harmonisation? Only if copyright law raises more sensitive political or cultural concerns than other areas of law should it be seen as special, protected and peculiarly national. ${ }^{100}$ We suggest that it is not so different and should not be treated as so special.

All law, from a socio-economic viewpoint, has always had a strong basis in localisation; limiting laws territorially is a way of localising them to a pre-defined area. Indeed, this desire for localisation is reflected by the literature on subsidiarity, ${ }^{101}$ which is derived from the Papal Encyclical Quadragesimo Anno:

Just as it is gravely wrong to take from individuals what they can accomplish by their own initiative and industry and give it to the community, as also it is an injustice and at the same time a grave evil and disturbance of right order to assign to a greater and higher association what lesser and subordinate organisation can do. For every social activity ought of its very nature to furnish help to the members of the body, social, and never destroy and absorb them. ${ }^{102}$

Therefore, allowing laws to be made at the local level enables them to represent "historical, geographical condition[s], as well as [the] religious, ethical, economic and social requirements" of each social group. ${ }^{103}$ These requirements, it may appear, are evident from the many different philosophical traditions of copyright, discussed below, but these traditions are often used (or misused) to maintain the rigid division and territoriality at the heart of copyright law. However, beyond these high

99 Cf Esin Örücü "Diverse cultures and official laws: multiculturalism and Euroscepticism" (2010) 6 Utrecht Law Review 75, 78 and 87.

100 Graeme Austin, "Domestic Laws and Foreign Rights: Choice of Law in Transnational Copyright Infringement Litigation" (1999) 23 Columbia-VLA Journal of Law \& The Arts 1, 39 (this was in relation to the application of foreign law in private international law, but the point is the same).

101 For a brief discussion in the EU context: see Chapter 4, Part C.2.

102 Given in 1931; the concept has been linked to Aristotle, Thomas Aquinas and others: T. Stauffer, "Subsidiarity as Legitimacy" (1999) World Bank Institute, Intergovernmental Fiscal Relations and Local Financial Program Topic 3 (26 July-6 August 1999).

103 H. Valladão, "Private International Law, Uniform Law and Comparative Law" in Kurt H. Nadelmann, Arthur T. von Mehren and John. N. Hazard (eds), XXth Comparative and Conflict of Law Essays in Honour of Hessel Yntema (Sythoff, Leiden 1961), 98 at 99. 
level abstract traditions, many authors argue there are anthropological reasons for these divisions. Copyright laws, it has been suggested:

are a component of local cultural and information policies. As such, they express each sovereign nation's aspirations for its citizens: exposure to works of authorship and participation in their country's cultural patrimony. ${ }^{104}$

Similar is the argument that:

a nation's copyright laws lie at the roots of its cultural and intellectual climate. Copyright provides the inducement for creation and dissemination of the works that shape our society and, in an imperfect and almost accidental way, represents one of the foundations upon which freedom of expression rests. ${ }^{105}$

Thus, the harmonisation of copyright law might lead to the homogenisation of cultural policy and with it a loss of culture and identity. ${ }^{106}$ Yet, ironically, the fragmentation of the world into nation states enables copyright to provide a "cultural filter" and remove diversity and encourage homogenisation. ${ }^{107}$ This is further exaggerated when owners of copyright are vertically integrated (such as in the market of filmed entertainment ${ }^{108}$ ) and decide that they should exploit their wares only in

104 Jane Ginsburg, "International Copyright: From a 'Bundle' of National Copyright Law to a Supranational Code?" (2000) 47 Journal of the Copyright Society 265, 267.

105 Barbara Ringer, "The Role of the United States in International Copyright - Past, Present, and Future" (1968) 56 Georgetown Law Journal 1050, 1050; see also David R. Toraya, "Federal Jurisdiction over Foreign Copyright Infringement Actions - An Unsolicited Reply to Professor Nimmer" (1985) 70 Cornell Law Review 1165, 1169 ("[a] state possesses a sovereignty interest in preserving the socio-economic, cultural, and political benefits its copyright law intended to advance.")

106 Steven Mark, "Harmonization or Homogenization? The Globalization of Law and Legal Ethics - An Australian Viewpoint" (2001) 34 Vanderbilt Journal of Transnational Law 1173, 1178.

107 Fiona Macmillan, "Copyright's Commodification of Creativity" (2003)

ICFAI Journal of Intellectual Property Rights 53.

108 See Fiona Macmillan, "The Cruel @): Copyright and Film" (2002) European Intellectual Property Review 483, passim. 
a limited number of countries. ${ }^{109}$ This cultural filtering eventually controls the way a society views and constructs itself. ${ }^{110}$ It can thereby actually inhibit the development of similar cultures where they are situated in two different countries. ${ }^{111}$ The European Union has tried to balance cultural policy, and Europe's multiculturalism, with economic desires for similarity and sameness. ${ }^{112}$

What is difficult to grapple with is why copyright law is thought to be at the "root of [the] cultural and intellectual climate" of any nation, ${ }^{113}$ when each state's culture, particularly in the developed world, includes many diverse elements or cultures. Indeed, today's reality seriously compromises the apparently axiomatic equivalence of copyright and culture. The imposition of requirements under the international copyright treaties has greatly restricted a country's freedom to determine its copyright policy. It may be, therefore, that the proper question is not whether copyright law is part of cultural policy, but whether the further harmonisation of copyright law is going significantly to undermine a country's cultural policy.

Once, before the Berne Convention and before the TRIPS Agreement, it might have been strongly arguable that a country could adopt its own copyright policy and this might have a significant effect on its own cultural policy. In Western countries at least, the importance of freedom to adopt an individual copyright policy to represent cultural differences appears to be trumped by a desire for other countries to adopt sufficient standards to protect the works of one another's nationals. This is

109 See Ann Capling, “Gimme shelter!” Arena Magazine, February/March 1996, 21 where it is suggested that the corporations who control $70 \%$ of the global music market only release $20 \%$ of their works in Australia.

110 Rosemary Coombe, The Cultural Life of Intellectual Properties (Duke University Press, Durham, NC 1998), 100-129.

111 Of course, attempts to control information flow can be a response of the State as well.

112 The market for copyright goods is rarely demarcated by national boundaries; rather they depend on language borders. There is a large market for French language books in the French speaking world, but only a limited market outside it. Where countries are divided linguistically, such as Belgium, the literary market will also be divided down that line. However, since the creation of the European single market the linguistic barriers, rather than national barriers, set the confines of the market.

113 Although, paradoxically, Lord Mustill has observed that "the essence of culture is heading now, not towards internationalism but non-nationalism": Lord Mustill "What are Judges For?", 23rd F.A. Mann Lecture, 1999 (unpublished). 
exemplified by a 1986 Recommendation of the Council of Europe ${ }^{114}$ in which the parties recognise that "copyright and neighbouring rights represent an essential instrument in the cultural policies of governments, aimed at promoting creation and ensuring and facilitating broad public access". ${ }^{115}$ Yet the recommendation is concerned with Member States adhering to international treaties and taking steps to prevent piracy. In practice, therefore, the relationship between cultural policy and copyright often amounts to little more than a way to achieve more protection for "right" holders. ${ }^{116}$

Indeed, our view of harmonisation is one of co-operation towards an agreed standard, rather than of an outsider imposing a standard on the European Union or the United States. Thus, the parties can negotiate and agree to allow for those things which are particularly culturally important to one another. Hostility and resistance to harmonisation usually comes when the rules are imposed from outside, not agreed upon from within. ${ }^{117}$ A rule or law from one country which another agrees to adopt is rarely disagreeable to the exporting country and it is only when a rule has to be changed that the hostility and nationalism arise. ${ }^{118}$

It is important to understand what is meant by culture and a country's culture. Copyright law does indeed relate to a country's culture but in a restricted sense, viewed through spectacles which can see only the arts, literature, music and film. ${ }^{119}$ These represent part, but only a small part, of a country's culture (albeit all of its cultural policy). Employment law

114 Recommendation No R (86) 9 adopted 22 May 1986 (this was a Council of Europe and not EEC/EU recommendation).

115 Recommendation No R (86) 9 adopted 22 May 1986, Sixth Recital.

116 It might be said that this is because right holders are (or at least were) particularly active and successful at lobbying at the international level. However, this is equally true at the national level and so if the national policy and international policy are to be the same there is little practical difference in retaining the national autonomy.

117 See Ruth Sefton-Green, "Multi-culturalism, Europhilia and harmonization: harmony or disharmony" (2010) 6 Utrecht Law Review 50, 58.

118 For an interesting comparison see Ralf Michaels, "Code vs Code: Nationalist and Internationalist Images of the Code Civil in the French Resistance to a European Codification" (2012) European Review of Contract Law 277, 289-290.

119 Although the creative industries can also be seen as incredibly wide, covering all those who are creative including those in advertising, computer programming and so forth: see Department of Culture Media and Sport, Classifying and Measuring the Creative Industries (DCMS: London, April 2013); also see Johanna Gibson, The Logic of Innovation: Intellectual Property, and What the User Found There (Ashgate, Farnham 2014), 12-16. 
governing the relationship between employees and employers and the responsibilities and rights they share can represent a culture and indeed a cultural identity far more than the country's literature or art. The rules of land ownership and the culture of renting or buying property defines a country's culture as does its view of consumer protection versus freedom of contract. Abortion laws, divorce laws and privacy laws each have cultural implications. It is not therefore that copyright law is not part of cultural policy - it is of course - but so at some level are all laws. In that sense copyright is not special. Culture is. So copyright law warrants no greater restriction - and due to the extensive international standards already existing, maybe less - than other laws during any moves towards harmonisation. As Rossett suggests:

There is a tendency for lawyers to behave as though they are the ones who decide whether law is unified, harmonious, or conflicting. To some extent they do, but harmonisation is primarily driven by business practice, not by the grand theoretical structures of legal scholars. ${ }^{120}$

\section{THE PERCEIVED DIVIDE: OF NATURAL RIGHTS, AUTHORS' RIGHTS AND PROPERTY RIGHTS}

\section{The United Kingdom and the United States}

We have attempted, in the preceding discussion, to clear away debris in an effort to focus on the core issues that must control discussion over both the desirability of a harmonised copyright regime and the kind of framework for harmonisation that may realistically be put in place. The aim is neither in some mechanical way to create a checklist of pros and cons of harmonisation nor to provide yet more fuel to the flames of nationalism or culture wars. Rather, we have suggested above that in approaching harmonisation specifically in the context of copyright law we abandon the talismanic attachment to fixed ideas but understand copyright as both a part of an entire legal structure and a part that is peculiarly involved in the modern transnational world. It is in that mode that we examine the degree to which there may be both hurdles to and opportunities for creation of a meaningful framework for transatlantic harmonisation of copyright law.

120 Arthur Rosett, "Unification, Harmonization, Restatement, Codification, and Reform in International Commercial Law" (1992) 40 American Journal of Comparative Law 683, 695. 
Generalisations can be useful aids to thinking, but they can also be dangerous and can inhibit clarity. So it is with copyright. We must deal with what may be seen as an over-generalised characterisation of the differing copyright regimes between the common law world and the author's rights countries of the European Union, a perceived difference that is considered inimical to harmonisation. ${ }^{121}$ It is common, albeit overly simplistic, to epitomise the differing foundations of their respective copyright laws as reflecting structural, endemic and traditional differences of such magnitude as to preclude anything but a continuation of the present piecemeal, minimum standards approach to a non-uniform uniformity. As is discussed below, we suggest that this preclusive epitomisation is neither necessary nor appropriate and that, whatever the strength of historical difference, the similarities in the real world challenges far outweigh the differences. Nevertheless, these apparent structural concerns must be considered and assessed.

It is easy to begin with a general premise, apparently distinguishing the differing bases of the copyright laws of the United States, the United Kingdom and Ireland on the one hand, and the author's rights (civil law) countries in the European Union, on the other, and from those apparently differing beginnings postulate a fundamental incompatibility. We thus tend to encapsulate the entire civil law copyright world within an "authors' rights/natural rights" cocoon in order to separate it from the common law's "instrumental" or "bargain" model, and thus conclude the inappropriateness of the very idea of any form of harmonisation. In a recent dissenting opinion of the US Supreme Court, Justice Steven Breyer (with the concurrence of Justice Alito) wrote: "[The] utilitarian view of copyrights and patents, embraced by Jefferson and Madison, stands in contrast to the 'natural rights' view underlying much of continental European copyright law", 122 and "sets us apart from continental Europe and inhibits us from harmonizing our copyright laws with those of countries in the civil-law tradition". ${ }^{123}$ As one prominent commentator (and federal appellate judge) observed, US copyright law is

121 A simplified summary of the differences was presented by Paul Goldstein, "Copyright: The Donald C Brace Memorial Lecture" (1991) 38 Journal of the Copyright Society 109, but these represent only some of the different perspectives. A more detailed discussion is available in Daniel Burkitt, "Copyright Culture - History and Cultural Specificity of the Western Model of Copyright" (2001) Intellectual Property Quarterly 146.

122 Golan v Holder, 132 S.Ct. 873, 901 (2012).

123 Golan v Holder, 132 S.Ct. 873, 889, n.28 (2012). 
founded on one or another concept of societal benefit flowing from the grant of a limited monopoly:

The copyright is not a natural right inherent in authorship. [It] is not an inevitable, divine, or natural right that confers on authors the absolute ownership of their creations. It is designed rather to stimulate activity and progress in the arts for the intellectual enrichment of the public. ${ }^{124}$

Similarly, the Supreme Court has expressly stated that "copyright supplies the economic incentive to create and disseminate ideas".125 There certainly is a sound basis to distinguish the United States approach to copyright from that of the Civilian European states as the difference between this purposive, "bargain theory" and a European fundamental "natural" or "property right" foundation for copyright. ${ }^{126}$

In the beginning, however, it was not clear whether the United States was purely instrumentalist or mixed between natural rights and instrumentalist concerns. ${ }^{127}$ As early as 1834 the US Supreme Court had to deal with this conceptual issue, in Wheaton $v$ Peters. ${ }^{128}$ Although the Court's dissenters saw copyright as a natural, property right of the author arising from the act of creation rather than from governmental grant, a majority of the Court established as a bedrock principle of American copyright law that copyright, at least with respect to a published work, is solely a creature of statute and not a product of the common law. ${ }^{129}$ For the majority, the function of copyright lay not in recognition of an inherent authors' right, but in an instrumental role, a limited monopoly by which the public good would be furthered (the monopoly to provide incentive and the limitation to make the work ultimately available to the public).

124 Pierre N. Leval, "Toward a Fair Use Standard" (1990) 103 Harvard Law Review 1105, 1107; see Suntrust Bank v Houghton Mifflin Company, 268 F.3d 1257 (11th Cir. 2001).

125 Harper \& Row Publishers v Nation Enterprises, 471 U.S. 539, 558 (1985).

126 See e.g., Jonathan Griffiths, "Constitutionalising or Harmonising? - The Court of Justice, the Right to Property and European Copyright Law" (2013) 38 European Law Review 65.

127 Jane Ginsburg, "A Tale of Two Copyrights: Literary Property in Revolutionary France and America" in Brad Sherman and Alain Strowel (eds), Of Authors and Origins: Essays on Copyright Law (Clarendon Press, Oxford, 1994), 131 at $137-43$.

12833 U.S. (8 Pet.) 591 (1834).

129 The role of the common law was limited to protecting the rights of an author in an unpublished manuscript that was subsequently eliminated entirely by the Copyright Act of 1976. 
The Wheaton opinion also is helpful for its review of the then state of the law in England, observing: "Perhaps no topic in England has excited more discussion, among literary and talented men, than that of the literary property of authors." 130 As Justice M'Lean notes: "The question respecting the literary property of authors, was not made a subject of judicial investigation in England until 1760; and no decision was given until the case of Miller v Taylor ${ }^{131}$ was decided in 1769."'132 The Wheaton majority took pains to elaborate that the instrumental nature of copyright was consistent with the English courts' approach. But was it?

The United Kingdom's foundational copyright statute, the Statute of Anne, ${ }^{133}$ was entitled "An Act for the Encouragement of Learning, by vesting the Copies of printed Books in the Authors or Purchasers of such Copies, during the Times therein mentioned" and the preamble to the Act states that the Act was "for the Encouragement of learned Men to compose and write useful Books". When a new copyright was granted to engravings it was once more entitled "An Act for the Encouragement of the Arts of Designing, Engraving and Etching ..."134 and nearly half a century later when it was extended to linen designs it was once more entitled an "An Act for the Encouragement ..."135 and likewise for sculptures. ${ }^{136}$ This would suggest that copyright was clearly instrumental throughout its history in Britain.

But even as these enactments were being passed, other voices were raised. In the so called copyright debates (and copyright cases) ${ }^{137}$ it was argued that under the English common law (as opposed to its statutory cognates) copyright was a natural right and continued to exist as such. Indeed, Blackstone, in his Commentaries on the Laws of England,

13033 U.S. (8 Pet.) 591, 654 (1834).

1314 Burr 2303 (98 ER 201) (1769).

132 This statement is actually incorrect, there were "fragments" of cases and judicial investigations from the 1710s onwards: see Ronan Deazley, On the Origin of the Right to Copy (Hart Publishing, Oxford 2004), Chapter 3.

1338 Ann c. 19 (1710).

134 Engraving Copyright Act 1734 (8 Geo 2 c. 23).

135 Design Copyright Act 1787 (27 Geo III c. 38).

136 Sculpture Copyright Act 1798 (38 Geo III c. 71).

137 Lionel Bently and Brad Sherman, The Making of Modern Intellectual Property Law (Cambridge University Press, Cambridge 1999) is an excellent starting point for discussion of the literary property debate (for a detailed discussion see Ronan Deazley, On the Origin of the Right to Copy (Hart Publishing, Oxford 2004); also see Howard Abrams, "The Historic Foundations of American Copyright Law: Exploding the Myth of Common Law Copyright" (1983) 29 Wayne Law Review 1119). 
suggested that property as such was a natural right albeit one now protected by convention. ${ }^{138}$ The House of Lords' late eighteenth century decision Donaldson $v$ Beckett ${ }^{139}$ might have abolished (if it ever existed $^{140}$ ) this purported common law right with respect to published books, but the common law was relied upon in relation to unpublished works until the coming into force of the Copyright Act 1911.141 It is not necessary for us to resolve this recurring debate; what is clear, and all that we seek to show, is that the United Kingdom, now clearly "instrumentalist"142 once had a foot in each of the two camps.

Whether, as Wheaton postulated long ago, the then state of English law was "not free from doubt"143 as Justice Breyer observed in 2012, it is generally agreed that the Statute of Anne "granted authors (not publishers) and their assignees the 'sole Right and Liberty of printing' their works for limited periods of time in order to encourage them 'to compose and write useful Books'."144 Continuing, he postulates an instrumental English "bargain" theory of copyright:

As one historian has put it, "[t]he central plank of the ... Act was ... a cultural quid pro quo. To encourage 'learned Men to compose and write useful Books'

138 (1st ed, 1765-9) (Facsimile ed., University of Chicago Press, Chicago 1979) see Book 1, Chapter 8 where Blackstone supports conventions; and Book 2, Chapter I where he asserts that there is a natural right to property. It must be remembered that Blackstone was Counsel in Tonson v Collins (1762) 1 Black W 321 where he argued that there was a natural right to common law copyright (see Ronan Deazley, On the Origin of the Right to Copy (Hart Publishing, Oxford 2004), 142-7).

139 (1774) 4 Burr 2408 (98 ER 257); 2 Bro PC 129 (1 ER 837).

140 See Ronan Deazley, On the Origin of the Right to Copy (Hart Publishing, Oxford 2004); this work stems from an early work by Howard Abrams, "The Historic Foundations of American Copyright Law: Exploding the Myth of Common Law Copyright" (1983) 29 Wayne Law Review 1119.

141 Copyright Act 1911, s. 31; a discussion of this, and its refutation of a common law right ever existing, can be found in Ronan Deazley, Rethinking Copyright (Edward Elgar Publishing, Cheltenham, UK and Northampton, MA USA 2006), Part 1.

142 This is demonstrated in the approach of the two recent reviews commissioned by the UK Government: Andrew Gowers, Review of Intellectual Property (HM Treasury 2006) and Ian Hargreaves, Digital Opportunity: A Review of Intellectual Property and Growth (IPO, May 2011).

14333 U.S. (8 Pet.) 657 (1834).

144 Golan v Holder, 132 S.Ct. 873, 901 (2012), Breyer, J., dissenting (quoting from 8 Anne, c. 19, s. 1 (emphasis added in Breyer, J.'s opinion)). 
the state would provide a guaranteed, if temporally limited, right to print and reprint those works. ${ }^{145}$

Ultimately, the US and UK ${ }^{146}$ copyright law did indeed diverge from their common source in the Statute of Anne, but this divergence, apart from the not insignificant US constitutional constraints discussed in Chapter 3, does not appear to be structural, or part of some inherent difference in purpose; both essentially take an instrumental view of copyright, seeing the limited monopoly the law creates as a means to achieving a societal, rather than a personal, good. Both ground copyright law in more or less attenuated principles of property so that, to that extent, including copyright in the concept of "intellectual property" in the United States and in the United Kingdom is perfectly logical and understandable and consistent with their respective overall conception of the role of copyright in their respective societies.

\section{The Authors' Rights States of the European Union}

Analysis of copyright in the civil law (authors' rights) countries of the European Union is conceptually more problematic. It is apparent that the common law and civil law systems approach copyright law from different starting points. It is also clear that generalising on the author's right countries with respect to individual states is venturing into treacherous territory. Nevertheless, we may safely say that, in general, the civil law systems recognise a bipartite copyright scheme, contemplating within a unitary concept of "copyright" the separate constructs of moral rights (or "personality rights") and economic rights (or "property rights"). It is that cultural distinction, for example, that has made it difficult for the United States easily to embrace the droit moral, rather than the hybrid Visual Artists Rights Act intended to meet the minimal standards of the Berne Convention's moral rights requirement. ${ }^{147}$

Civil law systems are said to be founded on a "natural" rights or "authors' rights"” predicate ${ }^{148}$ rather than one of bargain or exchange. ${ }^{149}$ Thus, it was said that German legal policy was dominated by concern for

\footnotetext{
145 Golan v Holder, 132 S.Ct. 873, 901 (2012), quoting from Ronan Deazley "The Myth of Copyright at Common Law" (2003) 62 Cambridge Law Journal $106,108$.

146 Before the EU harmonisation projects.

14717 U.S.C. §106A.

148 Thus, in his Golan dissent, Justice Breyer refers to "the 'natural rights' view underlying much of continental European copyright law": Golan v Holder, 132 S.Ct. 873, 902 (2012) (Breyer, J., dissenting).
} 
the author's economic and social standing. ${ }^{150}$ Yet during the birth of authors' rights, France (probably seen as the epitome of this approach) was much more instrumentalist than it is seen to be today. ${ }^{151}$ It is clear that, as with any movement, "authors' rights" was a developing concept and during its development authors' rights became deontological in its approach $^{152}$ much in the same ways as the common law copyright systems became instrumentalist or "bargain" based for their copyright laws. It is clearly beyond the scope of this work meticulously to examine each of the copyright regimes in each of the various countries but we suggest, contrary to Justice Breyer's dissenting view, that such foundational differences that may exist are not sufficient to stifle any harmonisation project.

Rather, one may accept that, in general, the civil law systems emerged from an author-centric perspective without concluding that the result is a fundamental incompatibility or the inevitable unworkability of any scheme for harmonisation involving non-civil law systems. That is, systems may start from different premises without developing into mutually incompatible forms. Irrespective of the origins of a given copyright regime, one must consider it as it exists in the modern world and in relation to its neighbours. It is not sufficient simply to point to differences, particularly teleological differences. Rather, these differences must be weighed and evaluated to determine not the admitted existence of some difference but the extent to which such difference precludes

149 See Jane Ginsburg and Sam Ricketson, International Copyright and Neighbouring Rights: The Berne Convention and Beyond (2nd edn., Oxford University Press, Oxford 2005) at [1.04 and 1.05]; Stephen Stewart, International Copyright and Neighbouring Rights (2nd ed., Butterworths, London 1989), 6-7 (describing the European system of droit d'auteur).

150 Gerhard Schricker, "Harmonisation of Copyright in the European Economic Community" (1989) 20 International Review of Industrial Property and Copyright Law 466, 474.

${ }_{151}$ Jane Ginsburg, "A Tale of Two Copyrights: Literary Property in Revolutionary France and America" in Brad Sherman and Alain Strowel (eds), Of Authors and Origins: Essays on Copyright Law (Clarendon Press, Oxford, 1994) 131 at 144 et seq.

152 This shift is noted by, amongst others, Stina Teilmann, "Justifications for Copyright: The Evolution of le droit moral" in Fiona Macmillan (ed.), New Directions in Copyright Law, Vol 1 (Edward Elgar Publishing, Cheltenham, UK and Northampton, MA, USA 2005), 73. 
coming together where it matters. That is, when we speak of "harmonisation" we do not necessarily mean complete uniformity ${ }^{153}$ as opposed to consensus on matters of significance. In that sense, it is not at all clear that the teleological differences among the systems are indeed significant. In any event, the view of the Member States as to the nature and purpose of copyright is increasingly being overtaken by the approach of the European Union and it is to this we now turn.

\section{The European Union}

The approach of many EU Member States has not been reflected by the approach of the European Union (and more particularly, the European Commission), which has treated copyright as an instrument for economic and cultural growth and thus is more in line with the US (and UK) approach than it is with the history in most Member States. ${ }^{154}$ Essentially, the Commission appears instrumentalist and not deontological. ${ }^{155}$ This is particularly important for the implementation of a harmonisation scheme as it would be the European Union, rather than its Member States, that would be the vehicle for harmonisation. If that is so, the perceived hurdle of implementing more fully recognised user rights, with greater limitations and exceptions, may well be mitigated through adoption of a common instrumental foundation.

As the Court of Justice stated in C-227/10 Luksan:

153 Copyright law touches on the laws of: property, employment, competition (anti-trust) and industrial relations to name but a few; and so a harmonisation of substantive copyright law would not lead to uniform results in instances where these other areas of law might be engaged.

154 See Gerhard Schricker, "Harmonisation of Copyright in the European Economic Community" (1989) 20 International Review of Industrial Property and Copyright Law 466, 474.

155 It was not always so. When Adolf Dietz produced a report on behalf of the Commission as to the approach to copyright harmonisation in the 1970s it was founded on the author's personal and economic relations with the work (and not a bargain theory) and so relied on the workers and self-employed provisions: see Adolf Dietz, Copyright Law in the European Community (Sijthoff \& Noordhoff, Alphen aan den Rijn 1978) (this stance was, of course, partly adopted). 
the European Union legislature, taking the view that copyright protection was crucial to intellectual creation, sought to guarantee authors a high level of protection. Intellectual property was therefore recognised as an integral part of property. ${ }^{156}$

This statement is simply an acknowledgment of the position adopted from the early harmonisation projects. In 1990, the Commission indicated that a high level of protection was needed for the "continued creation in the field of European culture"157 and later justified harmonisation at a high level to bring about a "favourable environment which protects and stimulates creativity and innovative activities across Member States". ${ }^{158}$ Accordingly, the Commission saw the adequate protection of copyright as a necessary means to ensuring a return of investments in creative works; ${ }^{159}$ a purely instrumentalist approach. This stance looking more towards the interests of industry and away from the authors, as such, ${ }^{160}$ was seen as a firm departure from the traditions of the Member States. ${ }^{161}$ It was even suggested that the Commission was engaging in "copyright protection without the author". ${ }^{162}$

This instrumentalist view expressed by the Commission is also endorsed by the legislature. The Recitals to the Information Society Directive $^{163}$ and the Enforcement Directive ${ }^{164}$ both draw the link between strong intellectual property laws and investment in innovation and creation. Consistently, the Information Society Directive ${ }^{165}$ and the

156 C-277/10 Luksan v Van der Let [2013] ECDR 5, [66].

157 COM (90) 586 final, p. 23.

158 COM (96) 586 final, p. 2.

159 COM (96) 586 final, p. 7.

160 Margret Moller, "On the Subject of the Green Paper" (1989) 141 Revue Internationale $d u$ Droit d'Auteur 22, 28 (the discussion of private copying explains this (at 46)).

161 Margret Moller, "On the Subject of the Green Paper" (1989) 141 Revue Internationale $d u$ Droit d'Auteur 22, 24 (she also expressed concern with copyright being seen as equivalent to authors' rights (at 28)). Similar comments are found in André Françon, "Thoughts on the Green Paper" (1989) 139 Revue Internationale du Droit d'Auteur 128. The Green Paper these titles were referring to was the Green Paper on Copyright and the Challenges of Technology Copyright Issues Requiring Immediate Action, COM (88) 172 final.

${ }_{162}$ Gerhard Schricker, "Harmonisation of Copyright in the European Economic Community" (1989) 20 International Review of Industrial Property and Copyright Law 466, 475.

163 Directive 2001/29/EC, Recital (4).

164 Directive 2004/48/EC, Recital (9).

165 Directive 2001/29/EC, Recital (2). 
Rental Rights Directive ${ }^{166}$ recitals suggest strong rights are of fundamental importance for the economic and cultural development of the European Union.

Thus, from the perspective of the European Union as such, copyright is indeed instrumentalist; it is purposive specifically to promote growth and cultural development. This view that the protection of intellectual property is essential to stimulate innovation was reiterated in 2009. ${ }^{167}$ The EU instrumentalist approach is clear; the more difficult question will be how it will be implemented to maintain a more balanced, yet still instrumentalist, growth-enhancing framework consistent with the more traditionally author-oriented cultures of the individual Member States. We are not here dealing with absolutes, neither in the United States nor in the European Union. Labels such as "instrumentalist" and "author-centric" are just labels, signifying of course something of substance, but not immutable positions. Although, as discussed above, the approach of the European Union is essentially instrumental, it must be remembered that the author-centric approach was the basis of the Berne Convention as well as many of the subsequent treaties on copyright. ${ }^{168}$ Thus, as harmonisation must involve pressure on the author's right countries towards a more instrumentalist approach, there is also the political quid pro quo for the adoption of more author-centric approaches in the United States and elsewhere.

\section{A Bridge Too Far?}

Although we have been discussing perceived foundational differences, in fact, the outcomes in copyright controversies in common law countries and those in author's right countries are usually the same. Thus, an infringement of copyright in the United States is usually an infringement of copyright in France or Germany. The differences that arise are not in the general cases or indeed in a majority of cases but rather in a handful of what has been called hard cases. ${ }^{169}$ Harmonisation of copyright at a

\footnotetext{
166 Directive 2006/115/EC, Recital (3).

167 COM (2009) 532 final, p. 10.
}

168 See, for example, F. Willem Grosheide, "Paradigms in Copyright Law" in Brad Sherman and Alain Strowel (eds), Of Authors and Origins: Essays on Copyright Law (Clarendon Press, Oxford, 1994), 203 at 207.

169 Paul Geller, "Must Copyright be forever Caught between Marketplace and Authorship Norms?" in Brad Sherman and Alain Strowel (eds), Of Authors and Origins: Essays on Copyright Law (Clarendon Press, Oxford, 1994), 159 at 163 and 170 . 
practical level might therefore practically change little for businesses. Of course, we cannot be sure, but harmonisation allows us to avoid the duplicative costs of finding out, on a case-by-case basis, just how necessary some formal uniformity actually is.

More significantly, as we suggest below, acknowledging difference does not preclude harmonisation. As the various copyright regimes have grown and evolved to meet the modern and technological challenge to the creation and dissemination and exploitation of creative expression a merger of thinking in addressing the issues has been inevitable. An "authors" rights regimen is not necessarily one without limitations and exceptions on those rights; an instrumental regime is not inimical to authors' right. Neither of the apparently conflicting models is itself pure or inherently incompatible with the other. Indeed, the US Supreme Court majority in Golan v Holder was prepared to accept the dissenters' view of the difference between the US and the civil law systems without agreeing with their conclusion of fundamental incompatibility. ${ }^{170}$ The centripetal forces toward harmonisation "where it counts" are rapidly overtaking the shrinking cultural centrifugal forces.

170 Golan v Holder, 132 S.Ct. 873, at 889, n. 28 (2012). 